\title{
Assessing Drivers of Forest Conservation in Simancuang Village Forest, West Sumatra
}

\author{
Adelina Chandra ${ }^{1,5}$ (D) Dimas Fauzi ${ }^{2,5}$ (D) Fadhilla Husnul Khatimah ${ }^{3,5}$ (D) \\ Satrio Adi Wicaksono ${ }^{4,5}$ (D)
}

Accepted: 2 July 2021 / Published online: 7 October 2021

(c) The Author(s) 2021

\begin{abstract}
This study empirically assessed Social Forestry program implementation in Simancuang Village Forest or locally known as Hutan Nagari (HN) Simancuang in West Sumatra, Indonesia. We performed two analyses using primary and secondary data, namely propensity score matching to estimate the effects of the enactment of HN Simancuang in 2012 on forest cover loss and ordinal logistic regression (OLR) to predict the determinants of conservation awareness. The results of the forest cover analysis showed that forest cover loss in HN Simancuang between 2012 and 2019 was 0.038 percentage point lower than the adjacent protection forest. The relatively small impact was meaningful because although HN Simancuang is located much closer to settlements which increases the pressure on the forest, it could still maintain lower tree cover losses than the adjacent protection forest. This result indicated a certain degree of conservation awareness among HN Simancuang members, which prompted us to conduct a survey to 111 individuals from different households. To do this, we used the Ecosystem Services framework to conceptualise conservation awareness in HN Simancuang. Our OLR results showed that regulating and provisioning services of forests are the strong determinants of conservation awareness among the individuals in our sample. Our study indicates the need to implement social forestry program monitoring and evaluation, improve access to facilitation, and enhance agroforestry practice as the means to increase conservation awareness among forest-dwelling communities.
\end{abstract}

Keywords Village forest · Social forestry $\cdot$ Environmental services $\cdot$ Conservation awareness · Indonesia

Adelina Chandra

adelina.chandra@gess.ethz.ch

Extended author information available on the last page of the article 


\section{Introduction}

Forests play a vital role in providing natural resources, supporting rural livelihoods, and supplying environmental services (de Groot 1992; Maryudi and Krott 2012; Elis et al. 2019). Yet, forests are subject to deforestation and degradation due to anthropogenic pressures (Spracklen et al. 2015). At the local level, deforestation and forest degradation threaten rural populations, whose livelihoods depend on forest-based resources (Sunderlin et al. 2005). To reduce such pressures, community-based forest management (CBFM) has been promoted globally to reduce forest destruction while simultaneously improving rural development (Persha et al. 2011; Resosudarmo et al. 2014).

Approximately one-third of global forests are managed under various CBFM schemes (FAO 2016). In Indonesia, the government is mainstreaming participatory forest management through the Social Forestry ${ }^{1}$ (Perhutanan Sosial) policy, regulated primarily under the Minister of Environment and Forestry (MoEF) Regulation no. P9/2021 (see Supplementary Table 1). According to the regulation, Social Forestry consists of five schemes, namely community forests (hutan kemasyarakatan), village forests (hutan desa/nagari), community plantation forests (hutan tanaman rakyat), customary forest (hutan adat), and partnerships (kemitraan). As a common pool resource, the enactment of MoEF-managed forest estates (kawasan hutan) historically limits forest-dependent communities living inside or adjacent to the forests to extract and benefit from forest resources (Ostrom, Gardner and Walker 1994). With the growing view that involving local people to control forests proved to be effective in reducing both environmental degradation and poverty (Pokharel et al. 2007; Kanel and Acharta 2008; Ojha et al. 2009; Maryudi et al. 2012), Social Forestry was introduced to achieve this dual-goal by legally democratizing forest management to local communities.

Despite the Government's agenda to accelerate the progress of Social Forestry by allocating 12.7 million ha of forest area to local communities (Bappenas, 2014), the effectiveness and equity of Social Forestry programs at the local level is often questioned and contested (Agarwal 2001; De Royer et al. 2018). A systematic review of 86 studies on Social Forestry in Indonesia indicates that the success of Social Forestry in Indonesia is often primarily measured based on the direct economic contribution from forests to local livelihoods (Rakatama and Pandit 2020), for example, through sales of commodities and direct subsistence from forests (Lacuna-Richman 2012). However, other studies argue that the economic contribution of Social Forestry might not be sufficient to reduce the economic needs of the local people (Maryudi and Krott 2012; Galvin et al. 2018). Further, deforestation due to conversion to agricultural land might still occur along with the initial stage of economic growth among rural communities involved in CBFM (Tucker and Richards 1983; Richards and Tucker 1988; Agrawal et al. 2013), relegating environmental and forest degradation as a potential side effect of CBFM (Agrawal 2003).

\footnotetext{
${ }^{1}$ CBFM and Social Forestry can be used interchangeably and for consistency, we will use Social Forestry to better reflect the actual name of the CBFM program in Indonesia.
} 
We argue that direct economic improvement remains the main criterion determining successful Social Forestry in Indonesia. However, other benefits provided by forests, such as ecological improvement and social inclusion, should also be considered when assessing the achievement of Social Forestry. Unlike the other Social Forestry schemes, village forests are mainly aimed at developing the village and improving the welfare of its inhabitants through sustainable forest management (Riyanto 2008). The benefits gained by the locals depend on the status of the forest estate where the village forest is located (either in a protection forest or a limited production forest) and on the forest's biophysical characteristics (Bock 2012). For example, village forests within a protection forest may be used only for the production and collection of non-timber forest products.

A success story from the Lubuk Beringin village forest in Indonesia shows that local communities could even gain monetary benefits from conservation efforts directly through potential Payment of Environmental Services via REDD+(Feintrenie and Martini in Colfer and Pfund 2011; Bock 2012; Sari 2013). These findings are aligned with Birch et al.'s (2014) findings that the impact of village forests is largely influenced by socio-economic factors closely linked with the community's dependency on forests.

Our study site, Hutan Nagari Alam Pauh Duo Jorong Simancuang (HN Simancuang) in West Sumatra, represents an interesting case where the community members appear not to be economically and directly dependent on forests (e.g. through agroforestry practices). Yet, HN Simancuang, which was among the first village forests established in Indonesia, has also won the Wana Lestari Award from MoEF in 2016 (Muhammad 2019) in recognition of efforts conducted by HN Simancuang community members to conserve their forests (see MoEF regulation no. P.43/2016).

In this research, we aim to understand the factors driving community members to conserve forests. Using HN Simancuang as a case study might help us better understand the dynamics of Social Forestry practices on the ground and identify some driving factors of successful Social Forestry in Indonesia. First, we estimated the impact of village forestry in forest conservation by comparing tree cover loss trends between 2000 and 2019 in HN Simancuang with an adjacent protection forest. To ensure that the difference in tree cover loss between the two forest areas is due village forestry permit, we employed propensity score matching method to control the covariates that may confound deforestation (Santika et al. 2017; Carlson et al. 2018; Putraditama et al. 2019). Second, we assessed the driving factors behind the community's conservation awareness using an ordinal logistic regression (OLR) model based on data from a household survey we conducted in 2018. Together, these spatial and statistical analyses provide insights on the drivers that motivated local communities in forest conservation and how such drivers affected the forests after the designation of HN Simancuang.

\section{Conceptual Framework}

\section{Conservation Awareness}

To study the community's motivation in achieving conservation goals, such as minimising deforestation, we started from the concept of conservation awareness. 
Despite the wide range of literature discussing conservation awareness, there is no consensus on its definition. Some scholars see conservation as strict nature preservation for the sake of nature itself without considering its benefits for people (see Soule 2013), whereas others define conservation more broadly as the intended actions which contribute to establishing or maintaining good relations with nature (LeaderWilliams et al. 2010; Sandbrook 2015). The latter definition provides flexibility as it does not exclude human elements in nature protection. Further, Kaiser, Midden and Cervinka (2008) explain conservation behaviour or awareness as actions driven by conservation goals, i.e. protecting nature from any harm.

In the HN Simancuang's context, conservation awareness among the community has been present since the initial settlement and paddy fields were established in 1974 (Fauzi el al. 2019). According to the HN Simancuang management board (LPHN), ${ }^{2}$ there was an agreement among the dwellers that logging the forest would be prohibited as it serves as the village's primary water catchment. This rule was formalised and strengthened when the HN Simancuang permit was granted in 2012 (Fauzi et al. 2019). Under the terms of the permit, the community is not only prohibited from timber logging, but also encouraged to plant high canopy tree species to improve forest cover (Fauzi et al. 2019). These indicate at least two major forms of conservation awareness with regards to forest protection among the locals of $\mathrm{HN}$ Simancuang: (1) logging prohibition and (2) high canopy tree planting. Based on these aspects, we collected site-level empirical findings to better understand the conservation motives in HN Simancuang.

\section{Ecosystem Services}

Ecosystem services (ES) is an evolving concept that explains the active and passive utilisation of ecosystems to produce or support human wellbeing (Fisher et al. 2009). The Millennium Ecosystem Assessment (2005) was among the first to connect ES with human well-being by designating four ES categories: provisioning, regulating, cultural, and supporting services. The Millennium Ecosystem Assessment's ES classifications have been applied in multiple studies and environmental valuations (Joshi and Negi 2011; Lahjie et al. 2019). In 2010, The Economics of Ecosystems and Biodiversity attempted to emphasise and integrate biodiversity in ES and proposed four ES classifications outlined in Table 1.

Although ES framework has been criticised because the benefits are often limited to the direct ones that are commensurable with economic values, the ES framework provides a clear and relevant logic for policy and decision making concerning ecosystem management (Ellis et al. 2019). Therefore, the ES classifications outlined in Table 1 are used in identifying the predictors of conservation awareness among our

\footnotetext{
${ }^{2}$ LPHN or Lembaga Pengelola Hutan Nagari, often used interchangeably with LPHD or Lembaga Pengelola Hutan Desa or lembaga desa, is a village-level management committee established by local communities to manage their Social Forestry areas. The establishment of LPHN is a prerequisite for applying Social Forestry areas to MoEF (see MoEF Regulation no. P.9/2021, similar to the preceding MoEF regulation no. P.83/2016). We use LPHN throughout the paper.
} 
Table 1 Ecosystem Services classifications according to The Economics of Ecosystems and Biodiversity (The Economics of Ecosystems and Biodiversity 2010)

\begin{tabular}{ll}
\hline Ecosystem Services & Definition \\
\hline $\begin{array}{l}\text { Provisioning } \\
\text { Regulating }\end{array}$ & $\begin{array}{l}\text { The material outputs of the ecosystems, such as water, foods and raw materials } \\
\text { The role of ecosystems to regulate the surrounding environment, such as local } \\
\text { climate and natural hazards prevention }\end{array}$ \\
Habitat or Supporting & $\begin{array}{r}\text { Providing living spaces for the animals and plants as well as maintaining } \\
\text { biodiversity }\end{array}$ \\
The non-material benefits that humans gain from their interaction with the \\
ecosystem, such as recreational and spiritual purposes
\end{tabular}

respondents. This study draws heavily on provisioning and regulating services given that these services fit the local context and are perceived by the HN Simancuang's community.

\section{Research Methods}

\section{Study Area}

We conducted a field study in Kenagarian (village) Alam Pauh Duo, more specifically in the sub-villages (Jorong) of Simancuang and Karang Hitam Simancuang, which make up HN Simancuang (Fig. 1).

Both sub-villages were once intact forests, converted into paddy fields and settlement areas in 1974 (Fauzi et al. 2019). In 1992, the area became part of the Alam Pauh Duo village administration. Rice production has since become the main source of income for most households. Given that their livelihood is mainly supported by rice production, only a few people have cultivated non-timber forest products inside HN Simancuang, such as coffee, rubber, and fruits.

In 2010, the LPHN was established, participatory mapping was conducted, and the Social Forestry permit application was submitted under the facilitation of an NGO. In 2011, a temporary permit was granted, and in 2012 the full permit was issued for 35 years. The permit does not allow local communities to expand their agricultural land into the forest due to HN Simancuang's protection forest status. As stated in the LPHN's work plan submitted to the government, the primary objective of HN Simancuang's management is to secure water sources through forest protection.

As of 2018, 210 households and 720 individuals live in both sub-villages, covering 155 ha of paddy fields and approximately 25 ha of residential area. As is the custom in West Sumatra, local communities living around HN Simancuang follow the Minangkabau matrilineal culture. As such, women play a bigger role in the tenurial arrangement, whereby land is owned by the women while the men are responsible for managing it (Fauzi et al. 2019). This arrangement implies that the change in land 


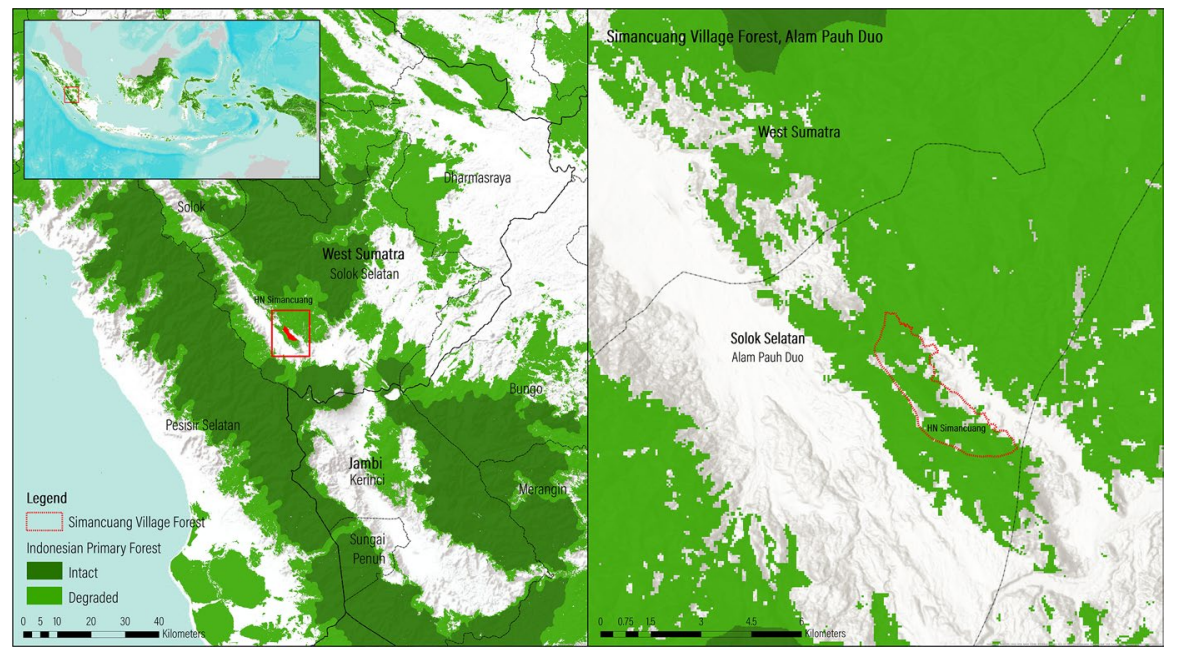

Fig. 1 Research location in Alam Pauh Duo, Solok Selatan District, West Sumatra Province. (Data source: Indonesian primary forests by Margono et al. 2014, and village forest by MoEF 2017)

ownership is dependent on the woman's decision. Under the Social Forestry context, forest lands are owned by the state, preventing land-use changes from occurring.

\section{Data Collection}

\section{Primary Data Collection}

Using a standardised questionnaire (see Supplementary Table 4), we conducted a household survey in HN Simancuang in April 2018 with the assistance of trained, college-educated local enumerators who spoke the local language. Upon data input, we investigated the quality of the data and corrected any mistakes in data input with the enumerators. The entire dataset was then processed with Stata. We interviewed a total of 111 individuals from different households who represented $15 \%$ of the total population and $53 \%$ of the households in both sub-villages. More specifically, 67 respondents lived in Jorong Simancuang, and 44 lived in Jorong Karang Hitam Simancuang.

The survey was conducted using a non-probability, convenience sampling method since we could not obtain households list in both sub-villages due to data privacy reasons. Convenience sampling has been commonly used where randomisation is not possible due to the large population size and limited available resources (Saumure and Given 2008; Etikan, Musa, and Alkassim 2017). Further, since our study design is non-experimental, using convenience sampling is appropriate. However, such a sampling could suffer from biases, which might make extrapolation to the population difficult (Hedt and Pagano 2011; Clapham and Nicholson 2014; Brodaty et al. 2014). 
To reduce the biases, we ensured that the respondents were evenly distributed geographically regardless of road accessibility. The criteria used in selecting our samples include (1) a minimum age of 18; (2) an understanding of households' income and assets (normally head of household or the spouse); and (3) a resident in either of the two sub-villages. We first identified the distribution of populations in both sub-villages and randomly visited the houses within both sub-villages that were readily available (see Henderson et al. 2009).

In addition to the survey, we conducted ten semi-structured interviews and a focus group discussion with the provincial forestry agency, local NGOs, head of village, heads of sub-villages, and several members of HN Simancuang. The purpose of the qualitative data gathering was to gain in-depth information on HN Simancuang history, community management and on-the-ground Social Forestry implementation. Prior to the fieldwork, a scoping study was conducted with an aim to gather preliminary insights for designing the survey and developing questions for the focus group discussion and semi-structured interviews.

Each respondent signed a consent form agreeing to voluntary participation, restricted use of data for research purposes, and personal data protection, among others. Respondents could refuse to answer any questions should they feel necessary. All these procedures complied with the academic research ethical standards (Flick 2014) and approved by the internal review board of the World Resources Institute (WRI) Indonesia.

\section{Secondary Data Collection}

We primarily used open-access observational data from various sources to represent variables in the propensity score matching for deforestation analysis (Table 2), which will be further explained in the next section. To ensure the robustness of the analysis, the variables used in this study were determined according to the local context in Alam Pauh Duo and literature.

\section{Data Analysis}

\section{Forest Cover Change Analysis}

We examined the impact of the designation of HN Simancuang on the forest cover by spatially calculating forest loss before and after the permit was granted in 2012 . We employed a quasi experimental design, namely propensity score matching using the MatchIt package in R by Ho et al. (2007), to predict the probability of treatment assignment given the covariates listed in Table 2 (Stuart and Rubin 2008; Austin 2011). We performed propensity score matching with 0.25 caliper, replacement and common support. Similar approaches have been used by several researchers focusing on estimating the impact of a certain policy or land use designation on the rate of deforestation (Gaveau et al. 2013; Santika et al. 2017; Carlson et al. 2018; Putraditama et al. 2019). To compare the distribution of treated and untreated cells, we 


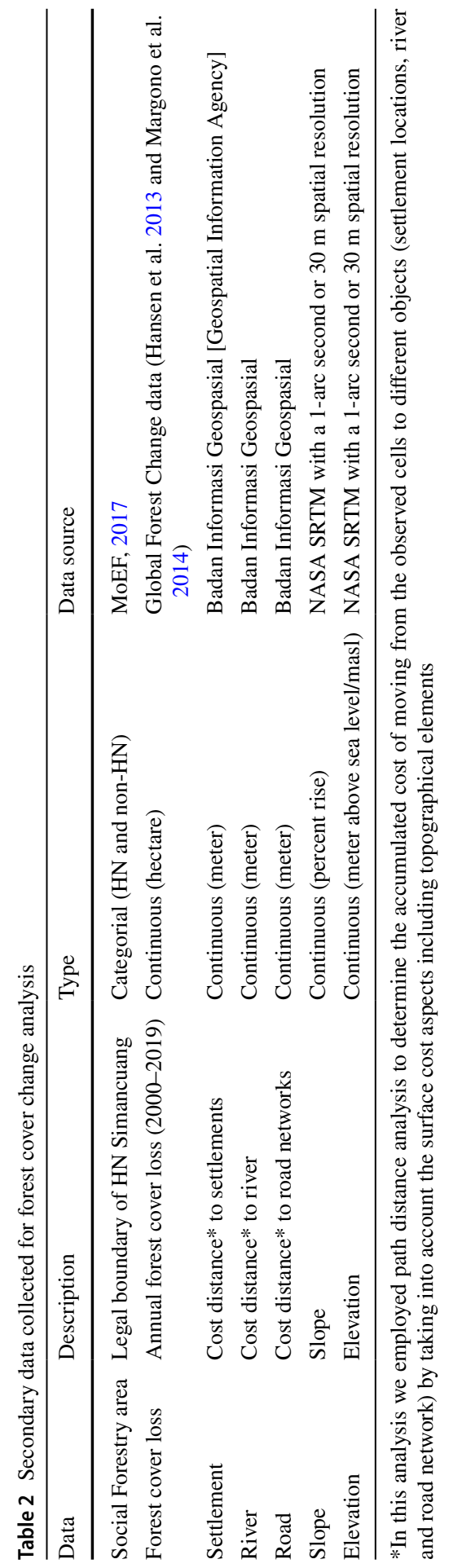




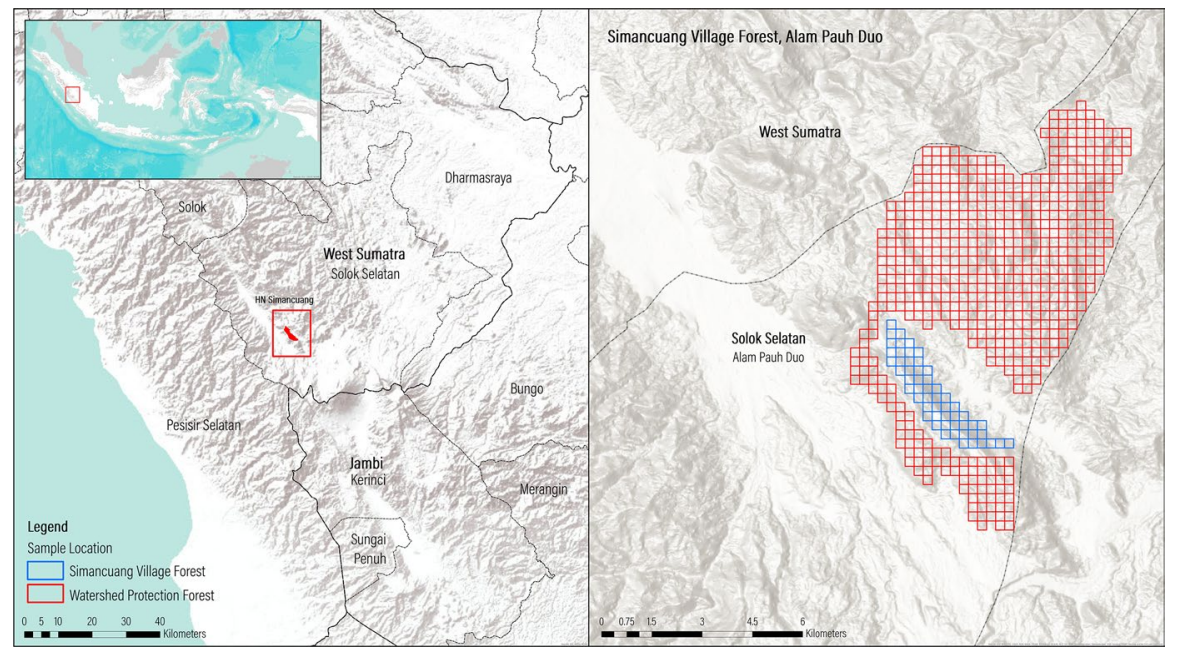

Fig. 2 Sampling areas, samples located in a HN Simancuang are marked in blue and b protection forest are marked in red. (Color figure online)

employed the Wilcoxon rank-sum test to compare both groups (Wilcoxon 1992). In our analysis, the treated cells are located within the HN Simancuang and the control cells are within the adjacent protection forest. We used Alam Pauh Duo, sub-district administrative boundary as our spatial extent.

Prior to estimating propensity scores, we analysed the existence of spatial autocorrelation of tree cover loss between 2012-2019 within the locus using the gstat package in $\mathrm{R}$ (Pebesma 2004). We found a semivariance asymptote (range) of $222 \mathrm{~m}$, which indicates that the cells closer than this range are affected by the cells nearby, and are therefore not independent. From this estimation, we created independent fishnet grids with an area of $270 \times 270 \mathrm{~m}$ or 7.3 ha each cell (see Fig. 2).

Forest cover loss data were treated as the outcome variable. Forest cover loss was produced by overlaying tree cover loss data by Hansen et al. (2013) with Indonesian primary forest boundary (Margono et al. 2014). The spatial resolution of the data is $30 \mathrm{~m}$, which means each pixel represents a $30 \times 30 \mathrm{~m}$ area with a value of 1 or "loss" if happened between 2012-2019 (after permit) and 0 if otherwise. Tree cover loss between 2000-2011 was set as the baseline following the temporary permit issuance. Meanwhile, the control factors were the biophysical drivers of deforestation, including the proximity to settlements, roads, and rivers, as well as slope and elevation (Laurance et al. 2002; Etter et al. 2006; Rasolofoson et al. 2015; Santika et al. 2017; Putraditama et al. 2019).

\section{Ordinal Logistic Regression}

We employed ordinal logistic regression (OLR) models to predict the factors that could potentially increase conservation awareness. An ordinal outcome variable is a categorical variable with a clear category-level ordering where the 
outcome value is higher than the previous one and is an extension of logistic regression where the response is linearly related to the independent variables (Williams 2016). The results of OLR were presented in odds ratio where we estimated the odds of having a one-point increase in the conservation awareness score. We used Stata to manage and analyse the dataset particularly using the 'ologit' command (Liu 2015).

There are two assumptions in OLR: no multicollinearity and proportional odds or parallel line assumptions. Multicollinearity can be tested using Variance Inflation Factors (VIF) after running an ordinary least square model. A VIF value of $>10$ indicates a harmful collinearity (Kennedy 1992; Hair et al. 1995). Besides, OLR should not violate proportional odds assumption to ensure that the estimated effects are the same across all categories. To do so, we ran a Brant Test after each OLR model where a significant $\mathrm{p}$-value indicates a violation of this assumption (Brant 1990).

We used two conservation awareness-related actions in this study as the outcome variables which were also emphasised in the Social Forestry's regulation, namely no logging and tree planting. As HN Simancuang is situated within the protection forest, MoEF Regulation No. P.9/2021 mandated that logging is prohibited, and tree planting and restoration activities are encouraged. The respondents were then asked their level of agreement with these two statements. On no logging, we asked, "I cannot cut the trees inside the HN Simancuang area". Meanwhile on tree planting, we asked, "I feel the need to plant high canopy trees inside of HN Simancuang". The responses for these two statements were captured using a five-point Likert scale where one represented the least agreement and five represented the most agreement. A higher agreement, thus, reflects a higher conservation awareness.

Due to the small sample size and to ensure the proportionality of the outcome variables, we recoded the scale from five to three by collapsing the adjacent scores. Such a method is quite common to deal with scalar or ordinal responses as it does not change the slope (Peterson and Harrell 1990; Greenland 1994). In this case, those answering 1-2 (very disagree and disagree) were recoded as 1 (disagree), those answering 3 (neither agree nor disagree) were recoded as 2 (neither agree nor disagree), and those answering 4-5 were recoded as 3 (agree). In this type of question, respondents might be reluctant to pick the most extreme values ( 1 and 5 ) which explained the significantly low $n$ in these two scores (see Supplementary Fig. 1).

We then attempted to predict the factors influencing conservation awareness. Similar to the Moutouama et al. (2019), the HN Simancuang community has relatively high dependencies on forest for its provisioning services (water sources and non-timber forest products) and regulating services (disaster prevention). To construct the dependency on forest resources, we used annual household income, agricultural land size, water access, flood and landslide experience as well as landslide risk perception. The models were controlled by intrinsic factors, i.e. understanding on Social Forestry and environmental protection motivation, and demographic factors. 
Table 3 Summary of the characteristics of control variables

\begin{tabular}{llll}
\hline Control variable & & $\begin{array}{l}\text { Protection forests } \\
(\mathrm{n}=611 \text { grid cells })\end{array}$ & $\begin{array}{l}\text { HN Simancuang } \\
(\mathrm{n}=55 \text { grid } \\
\text { cells })\end{array}$ \\
\hline Distance to Settlement (m) & Min & 625.5 & 525.4 \\
& Mean & 4001.0 & 1295.9 \\
& Max & 9132.5 & 2006.6 \\
Distance to Road (m) & Min & 54.0 & 895.7 \\
& Mean & 780.9 & 1676.5 \\
& Max & 2978.7 & 2739.4 \\
Distance to River (m) & Min & 69.5 & 609.7 \\
& Mean & 1785.7 & 1144.0 \\
Slope (\%) & Max & 4629.1 & 1655.2 \\
& Min & 12.4 & 14.7 \\
& Mean & 38.7 & 50.3 \\
Elevation (meter above sea level/ masl) & Max & 94.0 & 98.6 \\
& Min & 545.3 & 796.7 \\
& Mean & 936.8 & 991.7 \\
& Max & 1331.4 & 1248.5 \\
\hline
\end{tabular}

\section{Results}

\section{Forest Cover Change}

\section{Characteristics of HN Simancuang and the Adjacent Protection Forests in Alam Pauh Duo}

Situated in Bukit Barisan, a mountain range in Sumatra, the area surrounding HN Simancuang is relatively hilly. We summarised the biophysical characteristics of HN Simancuang and the adjacent protection forest in Table 3. Our analysis shows that HN Simancuang is generally higher (mean =991 masl), than the adjacent protection forests in Alam Pauh Duo (mean=936 masl). Despite the small elevation difference, on average, the slope in HN Simancuang (mean $=50.3 \%$ ) is steeper than the protected forests $($ mean $=38.7 \%)$. The morphological characteristics influence the spatial distribution of settlement in Alam Pauh Duo. Typically distribution of settlements in mountainous areas are clustered (Zhang et al. 2014). We found a similar pattern in Alam Pauh Duo. Despite its remoteness, the HN Simancuang area is more accessible (e.g. closer to road networks) in comparison to the protected forests. To some extent, this is expected as the village forest scheme is intended for the local communities under a village institution to manage the forest area within their village boundaries.

Further, the average distance to rivers is smaller in HN Simancuang $($ mean $=1143.9 \mathrm{~m})$ than in the protected forests $($ mean $=1785.7 \mathrm{~m})$, an indication 
Table 4 Control variables before and after matching analysis, after matching the number of units was reduced for both HN Simancuang (treatment) and the adjacent protection forest (control) to 30 and 27 grid cells respectively

\begin{tabular}{llllll}
\hline Variable & $\begin{array}{l}\text { Before/ After } \\
\text { Matching }\end{array}$ & Mean & & $\begin{array}{l}\text { Differences in means } \\
\text { HN \& Protection forests }\end{array}$ & $P$-value \\
\cline { 3 - 4 } & HN Simancuang & Protection forests & & \\
\hline \multirow{2}{*}{ Settlement } & Before & 1295.9 & 4001.0 & -2705.1 & 0.000 \\
& After & 1472.0 & 1668.7 & -196.7 & 0.235 \\
Road & Before & 1676.6 & 780.9 & 895.5 & 0.000 \\
& After & 1564.1 & 1917.0 & -352.9 & 0.316 \\
\multirow{2}{*}{ River } & Before & 1144.0 & 1785.7 & -641.7 & 0.000 \\
& After & 1234.7 & 1321.3 & -86.6 & 0.488 \\
Slope & Before & 50.3 & 38.6 & 11.7 & 0.000 \\
& After & 44.0 & 46.6 & -2.6 & 0.345 \\
Elevation & Before & 991.7 & 936.8 & 54.9 & 0.002 \\
& After & 1015.6 & 1024.0 & -8.4 & 0.631 \\
\hline
\end{tabular}

that water source protection was the aim of the local community when applying for the $\mathrm{HN}$ permit.

\section{Propensity Score Matching Analysis of Forest Cover Loss}

We attempted to statistically estimate the effect of HN Simancuang's permit issuance on the forest cover change that happened between 2012 and 2019. propensity score matching allows us to predict the probability of control cells being treated, thus allowing us to estimate the counterfactual group by accounting the covariates. The cells located entirely inside HN Simancuang areas were assigned as the treatment, while cells in the adjacent protection forest were assigned as controls. Through matching, we could reduce the selection bias, making the treatment and the control groups comparable. This could be observed from the differences in means of all control variables where the corresponding $\mathrm{p}$-values changed from significant at $1 \%$ level prior to the matching to be insignificant after the matching (Table 4).

We observed that tree cover loss that occurred in the HN Simancuang area between 2012 and 2019 was, on average, 0.038 percentage points lower than the loss occurring in the protection forests (Table 5). The Wilcoxon rank-sum test result indicates that the difference was statistically significant at $1 \%$ level $(p$-value $=0.003)$. Therefore, we can infer that the HN Simancuang designation has a lower forest cover loss compared to the protection forests as a result of Social Forestry implementation with an average treatment effect-on-the-treated of -0.038 percentage points.

In parallel to the propensity score matching analysis, we analysed the forest cover change in HN Simancuang (650 ha) between 2001 and 2019 using tree cover loss data by Hansen et al. (2013). We found that approximately $2.7 \%$ of the forest cover in the HN Simancuang has been lost throughout 2001-2019 (17.7 ha). We observed that the use of HN area was concentrated close to the settlement area for agroforestry, which may explain the relatively low deforestation rate within $\mathrm{HN}$ 
Table 5 The percentage of forest cover loss after the designation of HN Simancuang (2012-2019) before and after matching

\begin{tabular}{|c|c|c|c|c|c|}
\hline Comparison & & $\begin{array}{l}\mathrm{HN} \\
\text { Simancuang } \\
\text { (treated) }\end{array}$ & $\begin{array}{l}\text { Protec- } \\
\text { tion forests } \\
\text { (conrol) }\end{array}$ & Mean Difference & $P$-value \\
\hline \multirow{2}{*}{$\begin{array}{l}\text { Forest cover loss } 2012- \\
2019(\%)\end{array}$} & Mean unmatched & 0.020 & 0.015 & 0.005 & 0.622 \\
\hline & Mean matched & 0.005 & 0.043 & -0.038 & 0.004 \\
\hline
\end{tabular}

area. Considering that the community plays a crucial role in protecting the forest, understanding the driving factors that influence the local community's conservation awareness is central to reducing deforestation.

\section{Forest Conservation Awareness}

\section{Descriptive Statistics}

In contrast to most of the Social Forestry schemes which emphasise on the direct use of forests for timber forest products and non-timber forest product extraction, the establishment of HN Simancuang was aimed at securing the area from potential degradation that could affect water supply. The spatial data analysis shows that the main river which spans across Jorong Simancuang and Jorong Karang Hitam Simancuang starts in the HN Simancuang area, making it the primary water catchment area. As a result, HN Simancuang's role is central in maintaining water supply for the locals' consumption and agricultural production.

Based on our survey results, the respondents have relatively high environmental awareness in which tree planting awareness is relatively better distributed across respondents compared to no logging (Fig. 3). Even so, these trends still imply good environmental awareness among most of the respondents with a mean scores of 2.3 and 2.5 in a three-point Likert scale for no logging and tree planting awareness respectively. Table 6 provides greater details on these two outcome variables along with all covariates used in our models. Most of the respondents worked as a farmer or came from a farming household. They have lived in the area for, on average, 25 years, with only $37.8 \%$ of them having completed 9 -year compulsory education (middle school).

With a mean annual income of IDR18.4 million (USD1,273), respondents in HN Simancuang on average earned IDR1.5 million (USD105.9) per month or around $29 \%$ lower than the provincial minimum wage. However, it is important to note that $75.7 \%$ of the households surveyed owned rice fields where on average 1.3 tons of rice were harvested in 2017, and $41.3 \%$ of which was consumed by the household. Agriculture contributed to $80.3 \%$ of the respondents' income. Thus, even though the average income is below the provincial minimum wage, most of them are self-sufficient when it comes to staple food. 

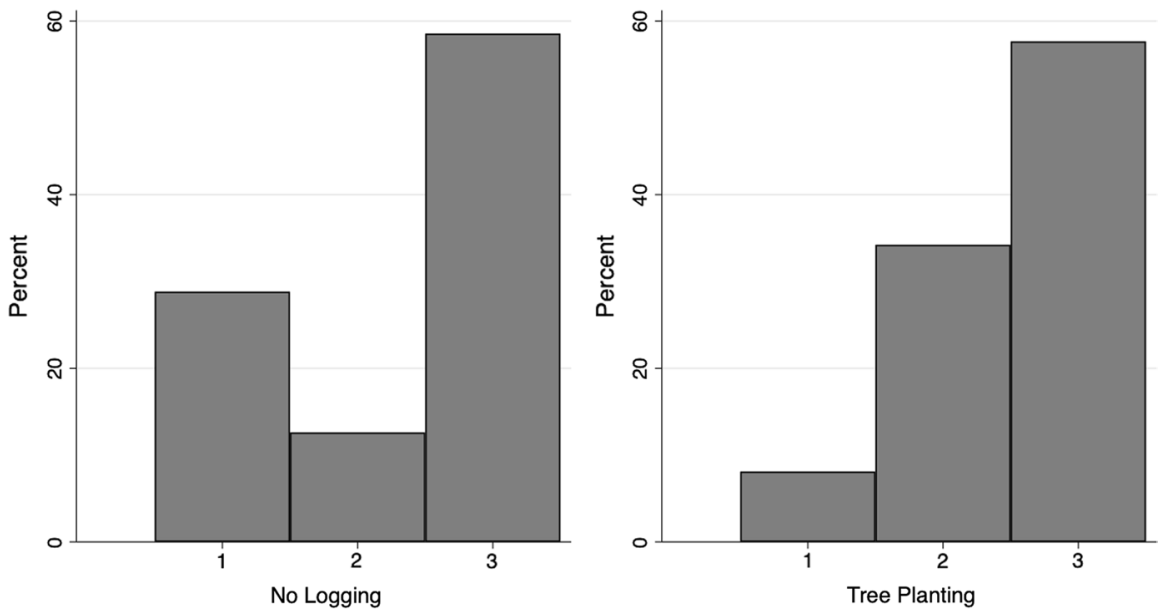

Fig. 3 Conservation awareness score distribution $(n=111)$

Table 6 Descriptive statistics of key variables

\begin{tabular}{|c|c|c|c|c|}
\hline Variable & Mean & S.D & Min & Max \\
\hline \multicolumn{5}{|l|}{ Outcome Variable } \\
\hline No Logging & 2.3 & 0.9 & 1 & 3 \\
\hline Tree Planting & 2.5 & 0.6 & 1 & 3 \\
\hline \multicolumn{5}{|l|}{ Provisioning Services } \\
\hline Total Annual Income (in 2018 USD rate) & $1,272.5$ & $2,221.3$ & 4.1 & 13,052 \\
\hline Agricultural Land Size (in Hectare) & 1.4 & 1.4 & 0 & 11 \\
\hline Good Water Access & $82.0 \%$ & 0.4 & & Dummy \\
\hline \multicolumn{5}{|l|}{ Regulating Services } \\
\hline Landslide Experience & $22.5 \%$ & 0.4 & & Dummy \\
\hline Flood Experience & $49.6 \%$ & 0.5 & & Dummy \\
\hline High Landslide Risk Perception & $46.9 \%$ & 0.5 & & Dummy \\
\hline \multicolumn{5}{|l|}{ Intrinsic Factors } \\
\hline Good Social Forestry Understanding & $37.8 \%$ & 0.5 & & Dummy \\
\hline Having Environmental Motivation & $87.4 \%$ & 0.3 & & Dummy \\
\hline \multicolumn{5}{|l|}{ Demographic Information } \\
\hline Farmers & $69.4 \%$ & 0.5 & & Dummy \\
\hline Household Size (\# of People) & 4.7 & 2.0 & 1 & 9 \\
\hline Length of Residency (Years) & 25.4 & 12.6 & 1 & 70 \\
\hline Completed Middle School & $37.8 \%$ & 0.5 & & Dummy \\
\hline Sample Size & 111 & & & \\
\hline
\end{tabular}

We also noted several environmental services that were perceived or identified by the HN Simancuang community. These services include, among others, provisioning and regulating services. The respondents managed on average 1.4 ha of agricultural 
land located inside and/or outside of HN Simancuang, mostly for water-intensive rice fields. Approximately $82 \%$ of the respondents expressed that they had good water access. As for regulating services, respondents reported that $22.5 \%$ of them experienced landslides while almost half experienced floods. These incidents have increased their risk perception on landslides, where approximately $47 \%$ expressed their concerns about landslides.

\section{The Drivers of Communities' Conservation Awareness}

When we asked the respondents about their motivation to protect the forest, more than $85 \%$ expressed environment-related reasons, including disaster prevention and water conservation. We then ran OLR models to see the relationships between one's conservation awareness and HN Simancuang's ES (Table 7).

We estimated the odds of having one-point increase in conservation awareness score, i.e. no logging and tree planting, using the odds ratio for each predictor variable. Generally, the OLR results for both conservation awareness indicate that regulating services of HN Simancuang are better predictors for no logging, while provisioning services explain the tree planting awareness better. For no logging awareness, there seems to be an association between logging and natural hazards perceived by the respondents, especially when they have experienced such an incident in their lifetime. On the other hand, tree planting awareness seems to be associated with 'benefits' from such activity where the provisioning services of $\mathrm{HN}$ Simancuang became a good predictor of this conservation awareness.

\section{No Logging}

There are six predictors of no logging awareness in HN Simancuang which were significant at the $10 \%$ level, namely water access, flood incident, landslide risk perception, farmer, household size, and education. Within the provisioning category, only good water access appeared to be significant where the odds of having a higher no logging score increased by, on average, 2.9 times for those perceiving to have good water access. On the other hand, the odds of having a higher no logging score increased by, on average, 3.9 and 3.5 times for those who have experienced floods in the past and those who have high-risk perception of landslides, respectively. These results indicate an association between tree removal with natural hazards, which has also been observed in the literature (Bradshaw et al. 2007; Malek et al. 2015).

We found a negative relationship between household size and no logging awareness, whereby the odds of having a higher no logging score decreased by, on average, $19.4 \%$ for every additional household member. During our interviews with LPHN and survey respondents, it appeared that logging for non-commercial purposes, such as building houses, was still acceptable in areas outside of $\mathrm{HN}$ Simancuang. This justification might have undermined the no logging awareness. A similar trend is observed among those who completed at least middle school education where the odds of having a higher no logging score would decrease 
Table 7 Ordinal logistic regression results on conservation awareness

\begin{tabular}{|c|c|c|}
\hline & $\begin{array}{l}\text { No logging } \\
\text { Odds Ratio }\end{array}$ & $\begin{array}{l}\text { Tree planting } \\
\text { Odds Ratio }\end{array}$ \\
\hline \multicolumn{3}{|l|}{ Provisioning Services } \\
\hline Log Total Income & $\begin{array}{l}1.178 \\
(0.219)\end{array}$ & $\begin{array}{l}1.809 * * * \\
(0.408)\end{array}$ \\
\hline Agricultural Land Size & $\begin{array}{l}1.057 \\
(0.242)\end{array}$ & $\begin{array}{l}1.608^{*} \\
(0.427)\end{array}$ \\
\hline Good Water Access & $\begin{array}{l}2.870 * \\
(1.627)\end{array}$ & $\begin{array}{l}3.286^{*} \\
(2.027)\end{array}$ \\
\hline \multicolumn{3}{|l|}{ Regulating Services } \\
\hline Landslide Experience & $\begin{array}{l}0.827 \\
(0.491)\end{array}$ & $\begin{array}{l}2.947 \\
(2.048)\end{array}$ \\
\hline Flood Experience & $\begin{array}{l}3.910 * * \\
(2.101)\end{array}$ & $\begin{array}{l}0.341 * \\
(0.206)\end{array}$ \\
\hline High Landslide Risk Perception & $\begin{array}{l}3.480^{* *} \\
(1.848)\end{array}$ & $\begin{array}{l}4.156 * * \\
(2.503)\end{array}$ \\
\hline \multicolumn{3}{|l|}{ Intrinsic Factors } \\
\hline Good Social Forestry Understanding & $\begin{array}{l}0.767 \\
(0.213)\end{array}$ & $\begin{array}{l}2.708 * * * \\
(0.858)\end{array}$ \\
\hline Having Environmental Motivation & $\begin{array}{l}2.077 \\
(1.417)\end{array}$ & $\begin{array}{l}3.757^{*} \\
(2.850)\end{array}$ \\
\hline \multicolumn{3}{|l|}{ Demographic Factors } \\
\hline Farmer & $\begin{array}{l}2.675^{*} \\
(1.542)\end{array}$ & $\begin{array}{l}8.510 \text { *** } \\
(5.793)\end{array}$ \\
\hline Household Size & $\begin{array}{l}0.806^{*} \\
(0.095)\end{array}$ & $\begin{array}{l}1.030 \\
(0.136)\end{array}$ \\
\hline Length of Residency & $\begin{array}{l}1.021 \\
(0.024)\end{array}$ & $\begin{array}{l}1.014 \\
(0.027)\end{array}$ \\
\hline Completed Middle School & $\begin{array}{l}0.424 * \\
(0.221)\end{array}$ & $\begin{array}{l}0.914 \\
(0.511)\end{array}$ \\
\hline Observations & 111 & 111 \\
\hline Hosmer-Lemeshow P-Value & 0.143 & 0.531 \\
\hline McFadden Pseudo $\mathrm{R}^{2}$ & 0.179 & 0.359 \\
\hline Log Likelihood & -85.02 & -63.23 \\
\hline LR Chi ${ }^{2}$ & $37.11 * * *$ & $70.71 * * *$ \\
\hline
\end{tabular}

Robust standard errors in parentheses. Odds ratios are significant at $p<0.01^{* * *}, p<0.05^{* *}$, or $p<0.1^{*}$ level

by, on average, $57.6 \%$. One explanation for this is that people with higher education levels have more options to work in sectors other than agriculture, such as being an entrepreneur or government official. Even so, farmers were 2.7 times more likely to have higher no logging awareness than those who worked in other sectors. 


\section{Tree Planting}

We identified seven significant predictors of tree planting awareness in HN Simancuang, which are significant at the $10 \%$ level, namely income, agricultural land size, water access, landslide incident, Social Forestry understanding, environmental motivation, and occupation. For every one percent increase in annual income, the odds of having a higher tree planting score would, on average, increase by 1.8 times. Similarly, agricultural land size appeared to be a predictor of tree planting awareness whereby for every one hectare increase in one's agricultural land size, the odds of having a higher tree planting score increased by, on average, 1.6 times. These trends were likely associated with the fact that, on average, $83 \%$ of respondents' income came from agriculture, with farmers being 8.5 times more likely to have a higher tree planting score.

Moreover, those who perceived to have good water access were 3.3 times more likely to have a higher tree planting score. The benefit of HN Simancuang as the water catchment area, both for surface and groundwater, has been reflected in the ease of water access and the income which was derived mostly from water-intensive agricultural lands, such as rice fields. Similar to no logging awareness, landslide risk perception seems to be associated with tree removal, which increased the odds of respondents' awareness of tree planting by 4.2 times. Interestingly, respondents who have experienced floods were $66 \%$ less likely to have a higher tree planting score. Although trees or forests do not always work best for flood mitigation (Marapara et al. 2021), there seems to be a lack of understanding among the locals that under the right circumstances, trees and forests do reduce hydrological risks (Keesstra et al. 2018).

Further, we found that those having a good understanding of the Social Forestry program were 2.7 times more likely to have a higher tree planting score. In this case, local facilitators became the forefront of field implementation of the Social Forestry program, including in the $\mathrm{HN}$ scheme. Besides, they also introduced the needs of planting high canopy trees. Agroforestry trees were normally chosen to allow nontimber forest product's utilisation by the locals. Those having an environmental stewardship appeared to be 3.8 times more likely to have a higher tree planting score as opposed to those who did not.

\section{Goodness of Fit and Robustness Checks}

Both models appeared to have $\mathrm{Chi}^{2}$ values that were significant at $1 \%$ level, indicating that the regression coefficients are not equal to zero. The overall Hosmer-Lemeshow test also indicated an overall good fit of the models with a $p$-value of 0.14 and 0.53 for no logging and tree planting respectively (Fagerland and Hosmer 2017). We also tested two key assumptions in OLR, namely multicollinearity and proportional odds assumption. The results showed a mean VIF value of 1.4 which indicated that there was no evidence of multicollinearity in our models. Meanwhile, proportional odds assumption was not violated given the $p>$ chi $^{2}$ values for both models were not significant, i.e., 0.37 for no logging and 0.54 for tree planting. As such, 
the estimated odds resulted from our models are proportional across all categories. Details of these tests are available in the Supplementary Tables 2-3.

\section{Discussion}

The tree cover analysis, and ordinal logistic regression that we have run showed three important points to discuss related to (1) deforestation reduction, (2) facilitation access, and (3) agroforestry enhancement.

\section{Reducing Deforestation at the Local Level Through Consistent Monitoring and Evaluation}

Improving socio-economic and forest conservation outcomes have become the expectations of Social Forestry. Yet, at the local level, such outcomes are difficult to see without clear evidence. Although both areas show low deforestation rates, the results on forest cover change indicates a lower trend in deforestation within HN Simancuang compared to the adjacent protection forest (see Table 5). Given that HN Simancuang is generally more accessible, thereby having greater socio-economic pressures than the adjacent areas, it is clear that the issuance of HN Simancuang permit has shown a positive contribution in avoiding deforestation. Considering the low deforestation rate within HN Simancuang, the conservation effort can be further improved.

Monitoring and evaluation is essential in controlling deforestation (Boucher et al. 2013; Nepstad et al. 2019). However, such an approach remains lacking at the local level (Burkard, 2009). This view is congruent with a study by Satria (2016) that the local authority in Solok Selatan District experienced difficulties in conducting monitoring and evaluation due to the lack of capacity and human resources to carry out field monitoring. Although there are several monitoring and evaluation frameworks from various NGOs that provide guidance for examining the implications of Social Forestry (see Rahayu et al. 2016; Sudarsono 2016; Fauzi et al. 2019), field monitoring is the most practical approach to utilising the frameworks. Besides, field monitoring is needed since not all local communities have the capacity to report to the authority. In fact, according to the regulation of the Directorate General of Social Forestry and Partnership no. 2/2017, monitoring should be carried out annually while evaluation should be done every five years. Thus, the monitoring and evaluation capacities of both local communities and authorities should be strengthened to ensure that the monitoring and evaluation is well-implemented as it has a huge potential to provide insights on how the local communities could better manage the forests.

\section{Improving Access to Facilitation}

While the community is expected to achieve Social Forestry objectives, access to facilitation, support, and training to help the community achieve the goals should 
be made available. Our analysis shows that improving the locals' understanding of the Social Forestry program will likely increase their conservation awareness, more specifically on how tree planting could help mitigate flood risks (see Table 7). As such, strengthening environmental education through facilitation that is tailored to promote better awareness on no logging and tree planting may produce positive forest conservation outcomes. However, unequal access to facilitation and support for rural communities remains a challenge in the agricultural and forestry sectors in Indonesia (Chandra 2020). The government could allocate resources to improve access to facilitation and guide facilitators (e.g. local agricultural extension services) to provide the knowledge needed by the local communities to achieve Social Forestry goals.

Forest patrol became one of the LPHN's planned activities which played a role in safeguarding the forest from disturbance, especially illegal logging and mining. Yet, this program has not been consistently implemented due to the lack of financial resources of the LPHN. It appeared that the LPHN and the HN Simancuang community-at-large became the sole actors when it comes to protecting the forest, and its inconsistency might have made forest protection efforts less optimal. In fact, more actors should be involved in the efforts to protect the forest, including the forest management unit or known locally as KPH, the village government, and the HN Simancuang community. Such a co-management approach has been implemented in Bangladesh for CBFM and it was proven to be quite efficient in deterring illegal loggers and improving forest cover from avoided deforestation (Nath et al. 2016).

A similar approach could be developed in the HN Simancuang and other Social Forestry areas in general. This co-management approach could improve conservation awareness among the community members who performed the patrol function (Nath et al. 2016). In doing so, proper budget allocation from the government to the KPH, village fund allocations from the village government, and forest provision taxes should be leveraged in addition to continuous facilitation from the KPH to the LPHN. A balance between conservation, government interests, and community empowerment should be pursued to ensure forest protection efforts to be efficient (Menzies 2007).

\section{Enhancing Agroforestry Practice and Market Access}

As indicated in the OLR results, income had a significant influence on tree planting awareness, but not on no logging. A body of literature has also emphasised on how CBFMs like the Social Forestry program in Indonesia have been able to reduce deforestation (Putraditama et al. 2019), whereby dependency on forest-based income from non-timber sources has encouraged forest protection as forest is considered as their livelihood asset (see Scoones 1998, 2015). To increase this conservation awareness, the implementation of agroforestry practice can be enhanced in the HN Simancuang. The trees that will be planted should be high canopy with potential non-timber forest product to diversify farmers' sources of income. A similar strategy has been done in Beringin Jaya Community Forest in Lampung, who received financial support from the MoEF's General Affairs Bureau to plant nutmeg trees in 
the forest area (Fauzi et al. 2019). Yet, since not all HN Simancuang members have agricultural plots inside HN areas, ensuring the inclusivity of agroforestry enhancement might be challenging. As such, there should be a clear mechanism that enables non-forest dwellers to participate, such as through the establishment of cooperatives that could facilitate non-timber forest product marketing with or without government support (see Nawir, Murniati, and Rumboko 2007).

However, evidence suggests that agriculture or forest income is associated with deforestation, for example, in the Amazon where timber extraction and land conversion activities are still rampant (Ojeda et al. 2020; Araujo et al. 2019). This could be a loophole in the current Social Forestry implementation in HN Simancuang, where forest patrol mechanism has not been implemented efficiently, if at all. Therefore, the enhancement of agroforestry and other non-timber utilisation of forest resources should be accompanied by a forest monitoring mechanism through the co-management approach that we have suggested.

\section{Conclusions}

This article aims to understand the impact of Social Forestry policy implementation in HN Simancuang, West Sumatra, Indonesia on curbing deforestation using forest cover loss as a proxy and how we could tap into community's conservation awareness to optimise forest protection efforts in Social Forestry areas. Using propensity score matching, we estimated that forest cover loss in HN Simancuang between 2012 and 2019 was, on average, 0.038 percentage point less as compared to Alam Pauh Duo protection forest. Although both areas generally have low forest cover loss due low accessibility, HN Simancuang is located closer to settlements which increases deforestation pressures due to human activities. Yet, our findings showed that HN Simancuang still had a lower deforestation rate than its adjacent areas, which were generally more inaccessible (less human threats and pressures).

In the case of HN Simancuang, we were interested in identifying factors that influence conservation awareness about no logging and tree planting. Our OLR results showed that no-logging awareness was mostly explained by the regulating services of HN Simancuang. Meanwhile, tree planting awareness was mostly predicted by both provisioning and regulating services where HN Simancuang became a major water catchment area for the river and groundwater required by agricultural fields and direct consumption. By understanding the factors that could predict conservation awareness, policies to enhance forest protection and curb deforestation in Social Forestry areas could be better targeted. Since no logging and tree planting are among the common rules in all Social Forestry schemes in protected forests, this approach does not only apply to HN Simancuang or other village forests, but also other Social Forestry schemes situated within protected forests.

Our findings suggest that the implementation of Social Forestry can be improved by maintaining consistent monitoring and evaluation, improving access to facilitation, and promoting the enhancement of agroforestry practice and market access at the local level. Given that the Social Forestry program allows forest-dwelling communities to protect the forest while managing it for livelihood support, we suggest 
that forest monitoring and evaluation should be conducted regularly to avoid a counterproductive outcome resulting from unsustainable agricultural practices. On top of these, Social Forestry could benefit from the implementation of co-management approach, especially for forest patrol and agroforestry enhancement.

Although the results of our study can point the policymakers to the right intervention to improve community's conservation awareness, we did not measure how HN Simancuang's conservation awareness was translated into actions. To better grasp the impact of community's conservation awareness, scholars and policymakers should explore the possibility of considering tree cover gain in addition to tree cover loss to get a better proxy of assessing how no logging and tree planting awareness are realised. This domain of study requires further research as there is a limited body of scholarship discussing this issue empirically.

In addition, it is important to note that the OLR estimates in this study are not meant for extrapolation in other contexts given the specific nature of the information and ecosystem services used in the study design. However, the methodological approaches that we employed in this study, i.e. propensity score matching for spatial analysis and OLR for conservation awareness, can be applied in different contexts, especially for measuring the effectiveness of community-based forest management.

Supplementary Information The online version contains supplementary material available at https://doi. org/10.1007/s11842-021-09489-2.

Acknowledgements This research was conducted in 2018 as a part of World Resources Institute (WRI) Indonesia's research project on Social Forestry's evaluation framework. We were grateful for the assistance from KKI-Warsi, West Sumatra to establish a connection with the HN Simancuang community. We also would like to express our gratitude to seven enumerators from Universitas Andalas, i.e. Dwi Laraswati, Retka Syamiyanti, Andri Magrifa, Bayu Febri, Daning Astia, Jelly and Nita. Without them, this research would not be possible. Finally, we would like to extend our appreciation to Professor Kimberly Nicholas and the reviewers for their insightful feedback and inputs.

Funding This research was made possible with the funding from the Norwegian Ministry of Foreign Affairs to the World Resources Institute (WRI) Indonesia. Open Access funding provided by ETH Zurich.

Open Access This article is licensed under a Creative Commons Attribution 4.0 International License, which permits use, sharing, adaptation, distribution and reproduction in any medium or format, as long as you give appropriate credit to the original author(s) and the source, provide a link to the Creative Commons licence, and indicate if changes were made. The images or other third party material in this article are included in the article's Creative Commons licence, unless indicated otherwise in a credit line to the material. If material is not included in the article's Creative Commons licence and your intended use is not permitted by statutory regulation or exceeds the permitted use, you will need to obtain permission directly from the copyright holder. To view a copy of this licence, visit http://creativecommons.org/licen ses/by/4.0/.

\section{References}

Agarwal B (2001) Participatory exclusions, community forestry, and gender: an analysis for South Asia and a conceptual framework. World Dev 29(10):1623-1648. https://doi.org/10.1016/S0305750X(01)00066-3

Agrawal A (2003) Sustainable governance of common-pool resources: context, methods, and politics. Annu Rev Anthropol 32:243-262. https://doi.org/10.1146/annurev.anthro.32.061002.093112 
Agrawal A, Cashore B, Hardin R, Shepherd G, Benson C, Miller D (2013) Economic contributions of forests. Background paper UN Forum on Forest.

Araujo C, Combes J-L, Féres JG (2019) Determinants of amazon deforestation : the role. Environ Dev Econ 24:138-156. https://doi.org/10.1017/S1355770X18000359

Austin PC (2011) An introduction to propensity score methods for reducing the effects of confounding in observational studies. Multivariate Behav Res 46:399-424. https://doi.org/10.1080/00273171.2011. 568786

Bappenas (2014) Rencana Pembangunan Jangka Menengah (RPJMN) tahun 2015-2019: Agenda Pembangunan Nasional. :311.

Birch JC, Thapa I, Balmford A et al (2014) What benefits do community forests provide, and to whom? a rapid assessment of ecosystem services from a Himalayan forest Nepal. Ecosyst Services 8:118127. https://doi.org/10.1016/j.ecoser.2014.03.005

Bock, Matthew J. (2012) Formalisation and Community Forestry in Jambi, Indonesia: Indigenous Rights, rural migrants, and the informal divide. The Josef Korbel Journal of Advanced International Studies -Summer 2012, Volume 4. [Online]- URL: http://www.du.edu/korbel/jais/journal/volume4/volume4 _bock.pdf (cited 7 March 2013)

Boucher D, Roquemore S, Fitzhugh E (2013) Brazil's success in reducing deforestation. Tropical Conserv Sci 6:426-445. https://doi.org/10.1177/194008291300600308

Bradshaw CJA, Sodhi NS, Kelvin S-H, Peh, and Barry W. Brook, (2007) Global evidence that deforestation amplifies flood risk and severity in the developing world. Glob Change Biol 13:2379-2395. https://doi.org/10.1111/j.1365-2486.2007.01446.x

Brant R (1990) Assessing proportionality in the proportional odds model for ordinal logistic regression. Biometrics 46:1171-1178. https://doi.org/10.2307/2532457

Brodaty H, Mothakunnel A, De Vel-palumbo M, Mpsych DA, Ellis KA, Reppermund S, Kochan NA et al (2014) Influence of population versus convenience sampling on sample characteristics in studies of cognitive aging. Ann Epidemiol 24:63-71. https://doi.org/10.1016/j.annepidem.2013.10.005

Burkard G (2009) Locating rural communities and natural resources in Indonesian law: decentralisation and legal pluralism in the Lore Lindu Forest Frontier, Central Sulawesi. J Agric Rural Dev Trop Subtrop 91:25-41

Carlson KM, Heilmayr R, Gibbs HK et al (2018) Effect of oil palm sustainability certification on deforestation and fire in Indonesia. Proc Natl Acad Sci USA 115:121-126. https://doi.org/10.1073/pnas. 1704728114

Chandra, (2020) To grip or to slip: Smallholder inclusion in sustainable palm oil certifications in Riau. Lund University

Clapham, C., and J. Nicholson (2014) Convenience Sampling. In: The Concise Oxford Dictionary of Mathematics. Oxford University Press. https://www-oxfordreference-com.libproxy1.nus.edu.sg/ view/https://doi.org/10.1093/acref/9780199679591.001.0001/acref-9780199679591-e-645.

de Groot RS (1992) Functions of nature : evaluation of nature in environmental planning, management and decision making. Wolters-Noordhoff BV

De Royer S, Van NM, Roshetko JM (2018) Does community-based forest management in Indonesia Devolve Social Justice or social costs? Int For Rev 20(2):167-180. https://doi.org/10.1505/14655 4818823767609

Directorate general of social forestry and environmental partnership (PSKL) no. 2/2017 on The guideline for Facilitation and Social Forestry Monitoring and Evaluation [Pedoman Pembinaa, Pengendalian dan Evaluasi Perhutanan Sosial]

Ellis EC, Pascual U, Mertz O (2019) ScienceDirect Ecosystem services and nature' s contribution to people : negotiating diverse values and trade-offs in land systems. Current Opinion Environ Sustain 38(June):86-94. https://doi.org/10.1016/j.cosust.2019.05.001

Etikan I, Musa S A, Alkassim R S (2017) Comparison of convenience sampling and purposive sampling. Am J Theor Appl Stat 5(1):1-4. https://doi.org/10.11648/j.ajtas.20160501.11

Etter A, McAlpine C, Wilson K et al (2006) Regional patterns of agricultural land use and deforestation in Colombia. Agr Ecosyst Environ 114:369-386. https://doi.org/10.1016/j.agee.2005.11.013

Fagerland MW, Hosmer DW (2017) How to test for goodness of fit in ordinal logistic regression models. Stand Genomic Sci 17(3):668-686

FAO (2016) Forty years of community-based forestry: a review of its extent and effectiveness. Food and agriculture organisation of the United Nations

Fauzi, Dimas, Adelina Chandra, Fadhilla Husnul Khatimah, and Satrio Adi Wicaksono (2019) Pengembangan kerangka evaluasi program perhutanan sosial di hutan lindung: studi kasus hutan 
kemasyarakatan (HKm) Dan Hutan Nagari (HN) (Developing evaluation framework for social forestry program in protected forest: case studies of a community forest and a village forest. WRI Indonesia Working Paper. Jakarta. https://wri-indonesia.org/en/publication/evaluasi-perhutanan-sosial.

Feintrenie and Martini (2011) 'Role of the district government in directing landscape dynamics and people's futures: lessons learnt from Bungo District, in Jambi Province' in Colfer and Pfund: collaborative governance of tropical landscapes. Earthscan

Fisher B, Turner RK, Morling P (2009) Defining and classifying ecosystem services for decision making. Ecol Econ 68(3):643-653. https://doi.org/10.1016/J.ECOLECON.2008.09.014

Flick U (2014) An introduction to qualitative research, 5th edn. SAGE

Galvin K, Beeton T, Luizza M (2018) African community-based conservation: a systematic review of social and ecological outcomes. Ecol Soc. https://doi.org/10.5751/ES-10217-230339

Gaveau DLA, Kshatriya M, Sheil D, Sloan S, Molidena E, Wijaya A, Wich S, Ancrenaz M, Hansen M, Broich M et al (2013) Reconciling forest conservation and logging in Indonesian Borneo. PLoS One 8:e69887. https://doi.org/10.1371/journal.pone.0069887

Greenland S (1994) Alternative models for ordinal logistic regression. Stat Med 13(16):1665-1677

Hair JF Jr, Anderson RE, Tatham RL, Black WC (1995) Multivariate data analysis, 3rd edn. Macmillan

Hansen MC, Potapov PV, Moore R et al (2013) High-resolution global maps of 21st-century forest cover change. Science 342:850-853. https://doi.org/10.1126/science.1244693

Hedt BL, Pagano M (2011) Health indicators : eliminating bias from convenience sampling estimators. Stat Med 30:560-568. https://doi.org/10.1002/sim.3920

Henderson TL, Sirois M, Chen A-C, Airriess C, Swanson DA, Banks D (2009) After a disaster : lessons in survey methodology from Hurricane Katrina. Popul Res Policy Rev 28:67-92. https://doi.org/10. 1007/s11113-008-9114-5

Ho DE, Imai K, King G, Stuart EA (2007) Matching as nonparametric preprocessing for reducing model dependence in parametric causal inference. Polit Anal 15:199-236. https://doi.org/10.1093/pan/ mpl013

Joshi G, Negi GCS (2011) Quantification and valuation of forest ecosystem services in the Western Himalayan Region of India. Ecosyst People 7(1):2-11. https://doi.org/10.1080/21513732.2011.598134

Kaiser FG, Midden C, Cervinka R (2008) Evidence for a data-based environmental policy: induction of a behavior-based decision support system. Appl Psychol Int Rev 57(1):151-172. https://doi.org/10. 1111/j.1464-0597.2007.00291.x

Kanel and Acharya (2008) Re-inventing forestry agencies: experiences of institutional restructuring in Asia and the Pacific. food and agriculture organization of the united nations regional office for Asia and the Pacific, Bangkok

Keesstra S, Nunes J, Novara A, Finger D, Avelar D, Kalantari Z, Cerdà A (2018) The superior effect of nature based solutions in land management for enhancing ecosystem services. Sci Total Environ 610-611:997-1009. https://doi.org/10.1016/j.scitotenv.2017.08.077

Kennedy P (1992) A guide to econometrics. Blackwell

Lacuna-Richman C (2012) Growing from Seed: an introduction to social forestry. Springer

Lahjie AM, Nouval B, Lahjie AA, Ruslim Y, Kristiningrum R (2019) Economic valuation from direct use of mangrove forest restoration in Balikpapan Bay, East Kalimantan, Indonesia. F1000Research. https://doi.org/10.12688/f1000research.17012.2

Laurance WF, Lovejoy TE, Vasconcelos HL et al (2002) Ecosystem decay of amazonian forest fragments: a 22-year investigation. Conserv Biol 16:605-618. https://doi.org/10.1046/j.1523-1739. 2002.01025.x

Leader-Williams N, Adams WM, Smith Robert J (2010) Trade-offs in conservation: deciding what to save. Wiley Blackwell

Liu Xing (2015) Applied ordinal logistic regression using Stata. SAGE

Malek Z, Boerboom L, Glade T (2015) Future forest cover change scenarios with implications for landslide risk: an example from Buzau Subcarpathians, Romania. Environ Manage 56:1228-1243. https://doi.org/10.1007/s00267-015-0577-y

Marapara TR, Jackson BM, Hartley S, Maxwell D (2021) Disentangling the factors that vary the impact of trees on flooding (a Review). Water Environ J : WEJ 35(2):514-529. https://doi.org/10.1111/wej. 12647

Margono BA, Potapov PV, Turubanova S et al (2014) Primary forest cover loss in Indonesia over 20002012. Nat Clim Chang 4:730-735. https://doi.org/10.1038/nclimate2277

Maryudi A, Krott M (2012) Poverty alleviation efforts through a community forestry program in Java. Indonesia JSD 5:p43. https://doi.org/10.5539/jsd.v5n2p43 
Maryudi A, Devkota RR, Schusser C et al (2012) Back to basics: considerations in evaluating the outcomes of community forestry. Forest Policy Econ 14:1-5. https://doi.org/10.1016/j.forpol.2011.07. 017

Menzies NK (2007) Our forest, your ecosystem, their timber: communities, conservation, and the state in community-based forest management. Columbia University Press

Millennium Ecosystem Assessment (2005) Ecosystems and human well-being: synthesis. Island Press

Ministry of Environment and Forestry (MoEF) (2017) Perhutanan sosial. https://geoportal.menlhk.go.id

MoEF Regulation no. P.9/2021 on Social Forestry Management [Pengelolaan Perhutanan Sosial]. Available online at http://pkps.menlhk.go.id/regulasi/read/42

MoEF Regulation no. P.43/MENLHK/SETJEN/KUM.1/5/2016 on General Guideline for Wana Lestari Competition and Appreciation [Pedoman Umum Penyelenggaraan Lomba dan Pemberian Apresiasi Wana Lestari]. Retrieved from http://ditjenpp.kemenkumham.go.id/arsip/bn/2016/bn765-2016.pdf

Moutouama FT, Sorotori S, Biaou H, Kyereh B, Asante WA, Natta AK (2019) Factors shaping local people' s perception of ecosystem services in the atacora chain of mountains, a biodiversity hotspot in Northern Benin. J Ethnobiol Ethnomed 15(38):1-10

Muhammad I (2019) Kolaborasi dalam pengembangan program perhutanan sosial pada hutan nagari di jorong simancuang, nagari alam pauh duo, kecamatan pauh duo, kabupaten solok selatan. Universitas Andalas

Nath TK, Jashimuddin M, Inoue M (2016) Community-based forest management (CBFM) in Bangladesh. Springer International Publishing

Nawir, Ani Adiwinata, Murniati, and Lukas Rumboko (2007) Conclusion and Recommendations. In: Forest Rehabilitation in Indonesia, Ani Adiwinata Nawir, Murniati, and Lukas Rumboko, (eds.) Bogor: Centre for International Policy Research (CIFOR), pp 223-234, http://www.cifor.org/publications/ pdf_files/Books/BNawir0701.pdf

Nepstad LS, James S, Gerber Jason D, Hill Lívia CP, Dias Marcos H, Costa Paul C, West (2019) Pathways for recent Cerrado soybean expansion: extending the soy moratorium and implementing integrated crop livestock systems with soybeans. Environ Res Lett 14(4):044029. https://doi.org/10. 1088/1748-9326/aafb85

Ojeda T, Zhunusova E, Günter S, Dieter M (2020) Forest policy and economics measuring forest and agricultural income in the ecuadorian lowland rainforest frontiers : do deforestation and conservation strategies matter? Forest Policy Econ 111:1-15. https://doi.org/10.1016/j.forpol.2019.102034

Ojha H, Persha L, Chhatre A (2009) Community forestry in Nepal: a policy innovation for local livelihood. Intl Food Policy Res Inst, 913

Ostrom E, Gardner R, Walker J (1994) Rules, games, and common-pool resources. University of Michigan Pers

Pebesma EJ (2004) Multivariable geostatistics in S: the gstat package. Comput Geosci 30:683-691. https://doi.org/10.1016/j.cageo.2004.03.012

Persha L, Agrawal A, Chhatre A (2011) Social and ecological synergy: local rulemaking, forest livelihoods, and biodiversity conservation. Science 331:1606-1608. https://doi.org/10.1126/science. 1199343

Peterson B, Frank EH (1990) Partial proportional odds models for ordinal response variables. J Royal Stat Soc. Series C (Applied Stat) 39(2):205-217

Pokharel BK, Branney P, Nurse M, Malla YB (2007) Community forestry: conserving forests, sustaining livelihoods and strengthening democracy. J Forest Livelihood 6(2):8-19

Putraditama A, Kim Y-S, Sánchez Meador AJ (2019) Community forest management and forest cover change in Lampung Indonesia. Forest Policy Econom 106:101976. https://doi.org/10.1016/j.forpol. 2019.101976

Rahayu, Subekti, Noviana Khususiyah, Gamma Galudra, and Muhammad Sofiyuddin (2016) Buku Pedoman Pemantauan dan Evaluasi Pengelolaan Hutan Desa Berbasis Masyarakat. Bogor: World Agroforestry Centre (ICRAF).

Rakatama A, Pandit R (2020) Reviewing social forestry schemes in Indonesia: opportunities and challenges. Forest Policy Econ 111:102052. https://doi.org/10.1016/j.forpol.2019.102052

Rasolofoson RA, Ferraro PJ, Jenkins CN, Jones JP (2015) Effectiveness of community forest management at reducing deforestation in Madagascar. Biol Conservation 184:271-277

Resosudarmo IAP, Atmadja S, Ekaputri AD et al (2014) Does tenure security lead to REDD+ project effectiveness? reflections from five emerging sites in Indonesia. World Dev 55:68-83. https://doi. org/10.1016/j.worlddev.2013.01.015

Richards JF, Tucker RP (1988) World deforestation in the twentieth century. Duke University 
Riyanto, B (2008) Hutan adat dan hutan desa: peluang dan kendala bagi masyarakat. working group on forest land tenure. Warta Tenure No. 5-April 2008.

Sandbrook C (2015) What is conservation? Oryx 49:565-566. https://doi.org/10.1017/S00306053150009 52

Santika T, Meijaard E, Budiharta S et al (2017) Community forest management in Indonesia: avoided deforestation in the context of anthropogenic and climate complexities. Glob Environ Chang 46:6071. https://doi.org/10.1016/j.gloenvcha.2017.08.002

Sari IM (2013) Community forests at a crossroads. University of Oslo

Satria, Hari Rizki (2016) Pengelolaan hutan berbasis masyarakat pada hutan nagari di jorong simancuang nagari alam pauh duo kecamatan pauh duo kabupaten solok selatan. Universitas Andalas, Padang. Retrieved from http://scholar.unand.ac.id/16651/5/skripsi\%20full.pdf

Saumure, K and Lisa MG (2008) Convenience sample. In: The SAGE encyclopedia of qualitative research methods, edited by Lisa M. Given, 125-125. Thousand Oaks, CA: SAGE Publications, Inc. https://doi.org/10.4135/9781412963909.n68.

Scoones, Ian (1998) Sustainable rural livelihoods: a framework for analysis. IDS Working Paper 72 (January 1998): 22. http://forum.ctv.gu.se/learnloop/resources/files/3902/scoones_1998_wp721.pdf.

Scoones I (2015) Sustainable rural livelihoods and rural development. Practical Action Publishing and Winnipeg, UK, Fernwood Publishing, CA

Soulé M (2013) The "new conservation.” Conserv Biol 27:895-897. https://doi.org/10.1111/cobi.12147

Spracklen BD, Kalamandeen M, Galbraith D et al (2015) A global analysis of deforestation in moist tropical forest protected areas. PLoS ONE 10:e0143886. https://doi.org/10.1371/journal.pone.0143886

Stuart EA \& Rubin DB. (2008). Best practices in quasi-experimental designs. Best practices in quantitative methods, (pp 155-176)

Sudarsono, Dwi (2016) Pedoman Monitoring dan Evaluasi (Monev) PHBM. Mataram: Yayasan Masyarakat Nusa Tenggara (SAMANTA).

Sunderlin WD, Angelsen A, Belcher B et al (2005) Livelihoods, forests, and conservation in developing countries: an overview. World Dev 33:1383-1402. https://doi.org/10.1016/j.worlddev.2004.10.004

The Economics of Ecosystems and Biodiversity (2010) The economics of ecosystems and biodiversity: mainstreaming the economics of nature: a synthesis of the approach, Conclusions and Recommendations of TEEB. http:/www.teebweb.org/wp-content/uploads/Study\%20and\%20Reports/Reports/ Synthesis\%20report/TEEB\%20Synthesis\%20Report\%202010.pdf

Tucker RP, Richards JF (1983) Global deforestation and the nineteenth-century world economy

Wilcoxon, F. (1992) Individual comparisons by ranking methods. In: Breakthroughs in statistics, Springer, New York, NY, (pp 196-202)

Williams R (2016) Understanding and Interpreting generalized ordered logit models. J Math Sociol 40:720. https://doi.org/10.1080/0022250x.2015.1112384

Zhang Z, Xiao R, Shortridge A, Wu J (2014) Spatial point pattern analysis of human settlements and geographical associations in eastern coastal China - a case study. IJERPH 11:2818-2833. https://doi. org/10.3390/ijerph110302818

Publisher's Note Springer Nature remains neutral with regard to jurisdictional claims in published maps and institutional affiliations.

\section{Authors and Affiliations}

\section{Adelina Chandra ${ }^{1,5}$ (D) Dimas Fauzi ${ }^{2,5}$ - Fadhilla Husnul Khatimah ${ }^{3,5}$ (D) Satrio Adi Wicaksono ${ }^{4,5}$ (D)}

1 Department Humanities, Social, and Political Sciences, Environmental Policy Lab, Sonneggstrasse 33, 8092 ETH Zurich, Switzerland

2 Lee Kuan Yew School of Public Policy, National University of Singapore, Bukit Timah, Singapore

3 Coordinating Ministry for Economic Affairs, Jakarta, Indonesia 
European Forest Institute, Kuala Lumpur, Malaysia

5 World Resources Institute Indonesia, Jakarta, Indonesia 